\title{
Microinvasive Squamous Cell Carcinoma
}

National Cancer Institute

\section{Source}

National Cancer Institute. Microinvasive Squamous Cell Carcinoma. NCI Thesaurus. Code C65178.

A squamous cell carcinoma with minimal stromal invasion. 